\title{
The Role of Employee Stock Option Plan to Reduce Earnings Management Actions
}

\author{
Namla Elfa Syariati, Bambang Subroto, Wuryan Andayani \\ Department of Accounting Faculty of Economics and Business University of Brawijaya \\ Jl. M.T. Haryono No.165 Malang, 65145, Indonesia
}

\section{ABSTRACT}

Keywords:

Earnings

Management;

Agency Theory;

ESOP

JEL Classification:

G32, G34, J54

This research aimed to investigate the influence earnings management to the compensation of the Employee Stock Option Plan (ESOP). Taking agency theory to explain the conflict between managers and shareholders. It was expected that ESOP would increase the managerial responsibility to companies, but the managers have abused it to gain more benefits for themselves. This research used simple linear regression and multiple linear regression analysis with a sample of 120 publicly traded companies listed on the Stock Exchange during 2011-2014. This study had one independent variable (ESOP) and controls four variables (managerial ownership, institutional ownership, board of directors and audit committees). The result of this study was that earnings management had a positive impact in improving employee compensation due to ESOP program. The existence of managerial ownership and commissioners could reduce earnings management actions in the implementation of the ESOP.

ABSTRAK

Kata Kunci:

Manajemen Laba; Agency Theory; ESOP

Penelitian ini bertujuan untuk mengetahui pengaruh manajemen laba terhadap kompensasi melalui Employee Stock Option Plan (ESOP). Pemilihan Agency theory untuk menjelaskan konflik kepentingan antara pihak manajer dan pemegang saham. Keberadaan ESOP dapat meningkatkan tanggung jawab pihak manajerial, namun pihak manajerial menyalahgunakan program ESOP untuk meningkatkan keuntungan mereka sendiri. Penelitan ini menggunakan analisis regresi linier sederhana dan regresi linier berganda dengan 120 sampel perusahaan go public yang tercatat di BEI selama 2011-2014. Penelitian ini memiliki satu variabel independen (ESOP) dan empat variabel kontrol (kepemilikan manajerial, kepemilikan institusional, dewan komisaris dan komite audit). Hasil penelitian ini menemukan bahwa manajemen laba memiliki dampak positif dalam meningkatkan kompensasi yang didapatkan karyawan dengan adanya program ESOP. Keberadaan kepemilikan manajerial dan dewan komisaris dapat mengurangi tindakan manajemen laba dalam pelaksanaan program ESOP.
\end{abstract}




\section{Jurnal Keuangan dan Perbankan | KEUANGAN}

Vol. 21, No. 3, Juli 2017: 425-435

Earnings management can be a dangerous disease within the company. Earnings management always involves two parties, namely the management (agent) who have a responsibility to the stockholders (principal). The conflict between the two parties led to the theory of agency (agency theory). Jensen \& Meckling (1976) argued that the agency theory describes the agent is a party contracted by the shareholders who are given the power to make a decision on behalf of shareholders. Raised the question of the agency (agency problem) because one party is more concerned with personal interests despite harm others (Sulistyanto, 2008).

Shareholders who are not directly involved in the company hand over the trust to the management to increase corporate profits. The company benefits as a benchmark for the shareholders in assessing the performance of employees. One of the actions of shareholders in appreciating the performance of their employees by giving bonus in the form of salary or incentive of equity.

Incentives equity by the company in the form of Employee Stock Option Plan (ESOP) or compensation to the management and employees are expected to align the interests of management and shareholders (Jensen \& Meckling, 1976). ESOP has been set in SFAS No. 53 (revised 2010) concerning payment of shares. Rewarding to management is expected to give incentive to management to improve its performance and foster a sense of responsibility towards the company. It can be recognized that more regulation new already available compared to SFAS No. 53 (revised 2010), will but the company being taken on period observation research from 2011-2014 will more corresponding with the old regulation because they guided him.

In Indonesia, equity incentive is better known as the ESOP or Employee Stock Option Program (POSK). The stock option program provides the opportunity for executive employees to own shares of the entity through giving (grants) stock options for his services. Ownership of the shares granted by the company to be an alternative to promote accountability responsible management and employees, so it will careful in making decisions (Herdinata, 2012). But the existence of the options considered misused by management to obtain higher compensation for their own benefit.

Asyik (2006) found that the executive employees of companies have implemented equity incentive can perform earnings management by adjusting earnings with lower earnings (income decreasing) and raise the profit (income increasing) reported after the date of grant of stock options do. Cheng \& Warfield (2005) and Bergstresser \& Philippon (2006) found that managers with high equity incentives to sell shares higher after the earnings announcement.

Earnings management actions in the implementation of the ESOP may harm companies and investors. Herdinata (2012) suggests the program ESOP could harm investors by playing a game earnings by reducing profit for each share. For ensure the implementation of the ESOP program properly, the necessary implementation mechanisms Corporate Governance (CG) is good. Cadbury (1992) also explained that corporate governance be a system to protect the company continues to run well. Corporate governance is becoming a major party as mediator between the board of directors, shareholders and auditors, as well as third-party sync relationship (Chen et al., 2010). Corporate governance be a good supervision to keep the implementation of the ESOP program would not be detrimental to shareholders. Kim \& Graskamp (2006) states that the ESOP will go well with the implementation of corporate governance mechanisms.

This study has some differences with previous research namely, ownership structure that consists of managerial ownership and institutional ownership, as well as the board of directors and the audit committee of control variables is not a major focus of research. Their managerial ownership and institutional ownership, as well as the 


\section{The Role of Employee Stock Option Plan to Reduce in Earnings Management Actions}

Namla Elfa Syariati, Bambang Subroto, Wuryan Andayani

board of directors and audit committee as control variables is expected to reduce the happening of earnings management. Based on the background formulated in this study that is whether equity incentive or ESOP effects on earnings management in companies go public Indonesia Stock Exchange (BEI) in the period 2011-2014.

\section{HYPOTHESES DEVELOPMENT}

Scott (2012) defines earnings management as following earnings management is the choice by a manager of accounting policies, or action affecting earnings, so as to active some specific report earnings objectives. Earnings management will make profit no corresponding with reality existing economy. The profits would be displayed follow desire management for shows good performance (Richardson, 1998). Rahayu \& Cahyati (2015) suggests earnings management be form intervention party management, with improve or lowered profit with make use of weaknesses of the accounting system allowed in standard accounting. Measurement of earnings management through discretionary accruals with how to reduce total accruals (TAC) and Non-Discretionary Accruals (NDA). An estimator can be seen in Table 1 .

\section{The Effect of Employee Stock Option Plan on Earnings Management}

Equity incentives or ESOPs are one way to improve employee performance and oversight of the company. In accordance with the rules of BAPEPAM in 2002 on ESOP, companies implementing ESOP program is expected to be a separate motivation for those who get bonus in the form of shares to be more responsible to the company. Schabus (2012) who finds that earnings management real is something It is common do in period post -SOX (Sarbanes Oxley), thus showing a negative relationship between earnings management and incentive equity because no all manager will do for the sake of price manipulation stock more is higher due to their ESOP follow.

ESOP is expected to be one of the employee motivation to improve its performance, more abused by manipulating financial statements in order to obtain a big bonus at the end of the year during the period of ESOP implementation. Research by Cheng \& Warfield (2005), which strengthened with research Bergstresser \& Philippon (2006) and Kusuma (2014), found incentive equity have influence significant to its happening earnings management, because found that the relationship between the $\mathrm{CFO}$ and $\mathrm{CEO}$ in the emergence an earnings management. Yermack (1997) also found that the weakness of the system in the company can make the management can play around the stock price. Shares owned by employees can present shareholding by way of the number of shares owned by employees against the number of shares issued in the previous year (Trebucq, 2004). ESOP measurement in accordance with measurement Asyik (2006) and Astika (2008) can be seen in Table 1

Based on explanation in above, earnings management can arise with the ESOP program. Such management and employee actions result in earnings management occurring due to a conflict of interest between management and owners (Jensen \& Meckling, 1976). On the basis of these researchers make ESOP as a major factor in research, so the hypotheses proposed is:

$\mathrm{H}_{\mathrm{a}}$ : equity incentive effect on earnings management

Reducing the occurrence of earnings management, implementation corporate governance mechanisms in the implementation of the ESOP may be a way to safeguard the interests differently by each party that are directly related to the company. Forms of corporate governance that is used in this research that institutional ownership, managerial ownership, audit committee and board 
of commissioners. The existence of corporate governance is expected to help control and suppress the occurrence of earnings management in the implementation of the ESOP program. The existence of control variables can describe and explain the relationship of a variable with more complete and good information (Hartono, 2010). Control variables are not a top priority in research to be tested and researched, but is Other variables that have effect in this study. Measurements of corporate governance into the control variable can be seen on Table 1.

\section{The Effect of Institutional Ownership on Earnings Management}

The ownership structure is not just one way to reduce the principal and agent conflict within the company, but it plays an important role as a third party to mediate the interests of the company that will not hurt one of them. There are several types of ownership structures by Jensen \& Meckling (1976), but researchers only focused into two forms of ownership structure consisting of institutional ownership and managerial ownership. Balsam et al. (2002), Midiastuty \& Machfoedz (2003), and Cornet et al. (2006), found that a large institutional ownership can reduce earnings management action, because of the greater supervision which will be done by the investor. Researchers use institutional ownership as a supporting variable to prevent earnings management as the findings of Hermeindito (2004). Hermeindito found that institutional ownership can control the actions of earnings management and improve the quality of financial reporting.

\section{The Effect of Managerial Ownership on Earnings Management}

Boediono (2005) and Iqbal \& Fachriyah (2005) found that managerial ownership can minimize the occurrence of opportunistic behavior of managers that have an impact on the reduction of earnings management. This may reflect that ownership by management can affect earnings management action. Managerial ownership is one of the supporting factors in decreasing earnings management. Research Partners (2002) proved that the large managerial stock ownership, the more consistent desire shareholders and investors so that managerial ownership does not affect the occurrence of earnings management (Mitra, 2002).

\section{The Effect of Audit Committee on Earnings Management}

Krishnan (2003) conducted a study on the occurrence earnings management in the year 1996 to 2000 in United States and discover the potential of earning management will be smaller with the existence of an audit committee. The large number of audit committees will increase supervision in financial reporting by management (Abbott et al., 2004). The study was supported by research Kumaat (2013) and Krishnan (2003) that the audit committee has no effect on earnings management.

\section{The Effect of Board of Commissioners on Earnings Management}

In accordance with the rules of the Jakarta Stock Exchange (2000) described that the proportion of the board of commissioners is at least 30 percent of all members of the board of commissioners. Commissioners should have a comparable amount to have is not the controlling shareholder (Wedari, 2004). Chen and Steiner (2000) found the characteristics of the commissioners be seen from the number of attendance, independence and tenure of the council relating to the level of fraud in a company. Wedari (2004) found the negative relationship and significant from board of commissioners and audit committees as a supporting factor that can reduce the action of earnings management. 


\section{METHODS}

Taking sample by using secondary data from the annual report publicly traded company listed on the Stock Exchange during 2011-2014. This study uses 30 companies that implement ESOP policy on period time the multiplied by 4 years' time observation produces 120 samples that can tested. Because company still guided PSAK No.53 (revised 2010) for period data retrieval, then new regulations no a standard in research this. This study uses the classical assumption test consisting of normality test, autocorrelation, heteroscedasticity test, and multicollinearity test.

The model used in this study did 2 analyses as follows. The model analysis in this study can be derived as follows:

$$
\begin{aligned}
\mathrm{ML}= & \beta_{0}+\beta_{1} \mathrm{PESOP}+\beta_{2} \mathrm{KeM}+\beta_{3} \mathrm{KeI}+\beta_{4} \mathrm{DeKom}+ \\
& \beta_{5} \mathrm{KA}+\mathrm{e}
\end{aligned}
$$

\section{Information:}

$\begin{array}{ll}\text { ML } & : \text { earnings management } \\ \beta_{\mathrm{O}} & : \text { constant } \\ \beta_{1 \cdot *_{5}} & : \text { regression coefficient } \\ \text { PESOP } \quad: \text { percentage of total shares options in } & \\ & \text { the form of outstanding ESOPs against } \\ & \text { shares outstanding in the previous } \\ & \text { year. }\end{array}$

KeM : percentage of ownership of management shares to total company's shares in year $t$

KeI : the percentage of institutional share ownership of total company's shares in year $t$

KAit : the number of audit committee members in year $t$

DeKom : percentage of independent commissioners to total commissioners in year $\mathrm{t}$

e : error
This study uses 1 dependent variable, 1 independent variable, and 3 control variables. The operational explanation of variables in this study, dependent variable is earnings management, using the Modified Jones Model to compute:

Total accrual:

$\mathrm{TACC}=\mathrm{NI}_{\mathrm{it}}-\mathrm{CFO}_{\mathrm{it}}$

Nondiscretionary accrual $(\mathrm{NDA})=\mathrm{TACC}_{\mathrm{t}} / \mathrm{TA}_{\mathrm{t}-1}=$ $\beta_{1}\left(1 / \mathrm{TA}_{\mathrm{t}-1}\right)+\beta_{2}\left(\Delta \mathrm{REV}_{\mathrm{it}} / \mathrm{TA}_{\mathrm{t}-1}\right)+\beta_{3}\left(\mathrm{PPE}_{\mathrm{it}} / \mathrm{TA}_{-t}\right)+\varepsilon \mathrm{t}$

$$
\begin{aligned}
\mathrm{NDA}_{\mathrm{t}}= & \beta_{1}\left(1 / \mathrm{TA}_{\mathrm{t}-1}\right)+\beta_{2}\left(\left(\Delta \mathrm{REV}_{\mathrm{t}}-\Delta \mathrm{REC}_{\mathrm{t}}\right) / \mathrm{TA}_{\mathrm{t}-1}\right)+\beta_{3} \\
& \left(\mathrm{PPE}_{\mathrm{t}} / \mathrm{TA}_{\mathrm{t}-1}\right)+\varepsilon \mathrm{t}
\end{aligned}
$$

Earnings Management (EM):

$\mathrm{EM}=\left(\mathrm{TACC}_{\mathrm{t}} / \mathrm{TA}_{\mathrm{t}-1}\right)-\mathrm{NDA}_{\mathrm{t}}$

EM : discretionary accruals for firm i in pe$\operatorname{riod} \mathrm{t}$

$\mathrm{NDA}_{t} \quad$ : non-discretionary accruals for firm i in period $\mathrm{t}$

$\mathrm{NI}_{\text {it }} \quad$ : net income of the company $\mathrm{i}$ in period $\mathrm{t}$

TACC $_{\text {it }}$ : total accrual for firm $\mathrm{i}$ in period $\mathrm{t}$

$\mathrm{CFO}_{\text {it }}$ : flow Operating cash flow for firm i in period $\mathrm{t}$

$\mathrm{TA}_{\mathrm{i}-\mathrm{t}} \quad$ : total assets of the company $\mathrm{i}$ in the previous period

$\triangle R \mathrm{~V}_{\mathrm{it}} \quad$ : change sales company $\mathrm{i}$ in period $\mathrm{t}$.

$\triangle \mathrm{RECt}$ : change of accounts receivable of company in period $t$.

$\mathrm{PPE}_{\mathrm{it}} \quad$ : asset remain firm $\mathrm{i}$ in period $\mathrm{t}$

$\varepsilon_{\text {it }} \quad:$ error

Independent variable is Employee Stock Option Plan (ESOP) to compute:

$\mathrm{PESOP}=\frac{\mathrm{JSK}}{\mathrm{JSB}}$ 


\section{Jurnal Keuangan dan Perbankan | KEUANGAN}

Vol. 21, No. 3, Juli 2017: 425-435

PESOP : percentage Employee Stock Option Plan (ESOP),

JSK : number of shares owned by employees, and

JSB : number of shares outstanding at the beginning or end of the previous year $(\mathrm{t}-1)$.

Control variables is corporate governance comprising:

Managerial ownership (KeM):

$\mathrm{KeM}=\frac{\text { Number of Shares of Management Party }}{\text { Total Shares Outstanding }} \times 100 \%$

Institutional ownership (KeI):

KeI $=\frac{\text { Number of Institutional Share Shares }}{\text { Shares Outstanding }} \times 100 \%$

Board of Commissioners $=$ the proportion of the board of commissioners (DeKom), which is the number of the board of commissioners of the company divided by the board of commissioners from internal parties to the company.

\section{RESULTS}

\section{Descriptive Statistics}

The results of descriptive statistics show the data for ESOP minimum is 0.00 . This means ownership of shares granted to employees is still not widely issued to the ESOP, although limits only 10 percent of the issued shares (Bapepam, 2006). Managerial ownership variables are known by dividing the number of manager shares with total outstanding shares. Based on the descriptive statistics obtained, the average value of managerial ownership is 0.13 . The minimum managerial ownership value is -2.00 and maximum of 1.64 , with a standard deviation of 0.86 . This descriptive statistic of managerial ownership proves that the low level of share ownership is given to the company. Institutional ownership variables can be determined by dividing the number of institutional shares with total outstanding shares. The average value of institutional ownership at 52.31, the minimum value in below 0,00 , and a maximum of 99, 00 , with a standard deviation of 26.32. The result of the description of institutional ownership proves that the number of shares owned by the stock is owned solely by an individual (WSKT). Descriptive statistics of variables commissioners found a mean value of 32.36 and has been qualified, published by BAPEPAM and BEI. As well as for audit committee variables measured by the number of members of the audit committee. The average value of the audit committee of 0.85 , the minimum value of 0.00 , and a maximum of 1.00 , with a standard deviation of 0,36 . In the audit committee, the researchers used a variable dummy, thus obtained the result that be how companies surveyed have an audit committee.

Table 1. Data Descriptive Statistics

\begin{tabular}{llcrrr}
\hline & N & Minimum & Maximum & Mean & Std. Deviation \\
\hline Earnings Management & 120 & .00 & 1.20 & .5243 & .27083 \\
ESOP & 120 & -2.30 & .01 & -1.4948 & .60716 \\
Managerial Ownership & 120 & -2.00 & 1.64 & .1283 & .85946 \\
Institutional Ownership & 120 & .00 & 99.00 & 52.3096 & 26.32081 \\
Board of Commissioner & 120 & .00 & 50.00 & 32.3625 & 12.05939 \\
Audit Committee & 120 & .00 & 1.00 & .8500 & .35857 \\
Valid N (listwise) & 120 & & & & \\
\hline
\end{tabular}




\section{Normality Test Results}

This research is also use study normality data analysis through assumption classic as test Kolmogorov-Smirnov, autocorrelation, heteroscedasticity test, and multicollinearity test. Results test show all the data of otherwise normal and feasible for processed on stages inferential statistical tests.

Table 2. Testing Kolmogorov-Smirnov

\begin{tabular}{lc}
\hline & Unstandardized Residual \\
\hline Kolmogorov-Smirnov & 0.566 \\
Asymp. Sig. (2-Tailed) & 0.906 \\
\hline
\end{tabular}

In simple linear regression analysis, the data used must meet the assumption of normality, that is the data used normal distribution. Based on the test Kolmogorov-Smirnov in Table 2, gained significance worth 0.906 , where the value is greater than $\alpha=0.05$. Values greater significance than $\alpha=$ 0.05 , it was decided to accept $\mathrm{H}_{0}$ and it is concluded that the data is normally distributed, i.e. the assumption of normality is meet.

\section{Autocorrelation Test}

Autocorrelation testing is done to determine whether there is autocorrelation in the model. The test is performed with the Durbin-Watson statis- tic test on Table 3 obtained Durbin-Watson value amounted to 1,955 and the Durbin Watson table for $\alpha=5$ percent, was found $\mathrm{d}_{\mathrm{U}}=1.7896$ and $4-\mathrm{d}_{\mathrm{U}}=$ 2.211 , in order to obtain $1,790<1,955<2,211$. Regression model will be better if there is no correlation between independent variables and control variables. Therefore, it can be concluded that there is no inter-residual autocorrelation.

\section{Heteroscedasticity Test Results}

This study tested using Glejser tester. Results of testing with Glejser tester as shown in Table 4 is known that the significance of all the independent variables is greater than 0.05 . These results can be concluded that the regression model is free from problems heteroscedasticity problems in ESOP variable, managerial ownership, institutional ownership, board of directors and audit committee.

\section{Multicollinearity Test Results}

Detect the occurrence of multicollinearity on research, visits of Variance Inflation Factor (VIF). VIF $>10$ illustrates that this research model happens multicollinearity and VIF $<10$, then the research is free from multicollinearity. Based on calculations in Table 6 can be seen that the results of the calculation results cannot be found VIF independent variables that have a VIF value of less

Table 3. Test Autocorrelation

\begin{tabular}{cccccc}
\hline Model & R & R Square & Adjusted R Square & Std. Error of the Estimate & Durbin-Watson \\
\hline 1 & $.426^{\mathrm{a}}$ & .182 & .146 & .25033 & 1.955 \\
\hline
\end{tabular}

Table 5. Heteroscedasticity Test

\begin{tabular}{|c|c|c|c|c|c|c|}
\hline \multirow{2}{*}{\multicolumn{2}{|c|}{ Model }} & \multicolumn{2}{|c|}{ Unstandardized Coefficients } & \multirow{2}{*}{$\begin{array}{c}\begin{array}{c}\text { Standardized } \\
\text { Coefficients }\end{array} \\
\text { Beta } \\
\end{array}$} & \multirow[t]{2}{*}{$t$} & \multirow{2}{*}{ Sig. } \\
\hline & & B & Std. Error & & & \\
\hline & (Constant) & .092 & .067 & & 1.368 & .174 \\
\hline & ESOP & .005 & .022 & .022 & .234 & .815 \\
\hline & Managerial Ownership & .018 & .016 & .112 & 1.189 & .237 \\
\hline & Institutional Ownership & .001 & .001 & 145 & 1.493 & 138 \\
\hline & Board of Commissioner & .000 & .001 & .031 & .304 & .762 \\
\hline & Audit Committee & .070 & .039 & .176 & 1.781 & .078 \\
\hline
\end{tabular}




\section{Jurnal Keuangan dan Perbankan | KEUANGAN}

Vol. 21, No. 3, Juli 2017: 425-435

than 10 as well as the tolerance value is greater than 0.10 . $S$ then it can be proven that this data is not contained between ESOP multicollinearity, managerial ownership, institutional ownership, board of directors, and audit committees in this study regression model.

\section{Hypothesis Testing Results}

This study obtained the results that can be summarized as follows:

The test hypothesis results, can be derived regression equation as follows:

$\mathrm{Y}=\beta+\beta_{1} \mathrm{ESOP}+\beta_{2} \mathrm{KeM}+\beta_{3} \mathrm{KeI}+\beta_{4} \mathrm{DeKom}+\beta$ ${ }_{5} \mathrm{KA}+\mathrm{e}$

$\mathrm{Y}=0.891+0.084 \mathrm{X}-0.059 \mathrm{~K}_{1}+0.000 \mathrm{~K}_{2}-0.007 \mathrm{~K}_{3}-$ $0.049 \mathrm{~K}_{4}$

Based on Table 2, it is known that the ESOP have a significant effect in increasing earnings management. ESOP significance value of 0.031 and $\mathrm{t}$ statistics of 2.187. These results illustrate that the existence of an ESOP program can increase the occurrence of earnings management. This happens because of the management's deviant behavior in following the ESOP program.

In addition to the ESOP, there are four control variables in this research that managerial ownership, institutional ownership, board of directors and audit committee. Results of the roller 4 variables control found only two variables that managerial ownership and control of the board of commissioners that can reduce the occurrence of earnings management.

The value of the coefficient of determination $\mathrm{R}^{2}$ (R-square of $18.2 \%$ ) show diversity in the variation of earnings management variables. The remaining portion of $82.8 \%$ is explained by other factors not discussed in this study. These results explain that the existence of control variables still have an impact in the management affect earnings, although influence pertained small. Managerial ownership, institutional ownership, commissioners, and committee audit can improve the diversity of the variation in earnings management.

Table 6. Test Multicollinearity

\begin{tabular}{lccccc}
\hline Model & ESOP & $\begin{array}{c}\text { Managerial } \\
\text { Ownership }\end{array}$ & $\begin{array}{c}\text { Institutional } \\
\text { Ownership }\end{array}$ & $\begin{array}{c}\text { Board of } \\
\text { Commissioner }\end{array}$ & $\begin{array}{c}\text { Audit } \\
\text { Committee }\end{array}$ \\
\hline Tolerance & .978 & .944 & .880 & .803 & .850 \\
VIF & 1.022 & 1.060 & 1.136 & 1.246 & 1.176 \\
\hline
\end{tabular}

Table 7. The results of hypothesis testing (with Control Variable)

\begin{tabular}{lcccc}
\hline \multicolumn{1}{c}{ Variables } & B & T count & Sig & Information \\
\hline Constant & 0.891 & & & Significant \\
ESOP & 0.084 & 2.187 & 0.031 & Significant \\
Managerial Ownership & -0.059 & -2.147 & 0.034 & Not Significant \\
Institutional Ownership & 0.000 & 0.529 & 0.598 & Significant \\
Board of Commissioner & -0.007 & -3.175 & 0.002 & Not Significant \\
Audit Committee & -0.049 & -0.705 & 0.482 & 0.050 \\
A & & & 0.426 & \\
R & & & 0.182 & \\
R Square & & & 5.059 & \\
F-Count & & & 2.295 & \\
F-Table $(0,05 ; 5 ; 114)$ & & & 0.000 \\
Sig. F & & & 1.981 \\
t-table $(0,025 ; 114)$ & & & \\
\hline
\end{tabular}




\section{The Role of Employee Stock Option Plan to Reduce in Earnings Management Actions}

Namla Elfa Syariati, Bambang Subroto, Wuryan Andayani

\section{DISCUSSION}

Based on these results it can be stated the alternative hypothesis is accepted that the ESOP effect on earnings management. Researchers found that the occurrence of increased earnings management in the presence of ESOP due to the increasing number of fraud committed by the management to obtain a big bonus from the company. Management will take advantage of existing opportunities by playing stock prices during the implementation of the ESOP program. The more the number of stock options held by employees, the greater the potential acts of cheating to be done.

The high level of abuse in this ESOP program is due dissatisfaction with the management side compensation obtained from company and bonus can be gotten. This push practice manipulation of financial statements in order to obtain greater bonuses. Manipulation of financial statements to earn a big bonus with the ESOP program is to play the stock price of the company. One modus operandi is the management will strive to reduce the share price, so that management wants to follow mem ESOP can buy cheaply. On the other hand, management will be increasing annual price of its shares to attract investors to shares in the company and increase the compensation earned during the ESOP program running.

The results of this study are supported by Cheng \& Warfield (2005), Bergstresser \& Philippon (2006), and Cheng et al. (2009) found that the presence of the equity incentive in the form of ESOP can increase the occurrence of manipulation of financial statements to keep the stock price remains and add the value of stocks which will be sold the future. Results the contradict with studies Schabus (2012) who finds role ESOP positive.

Based on the research that has researchers did, it was found that the board of directors and managerial ownership can reduce the occurrence of earnings management in the implementation of the ESOP. The existence of the commissioners can maximize oversight of the management in running the ESOP program in order to avoid practices that could harm the company. Moreover, the existence of managerial ownership is also can reduce earnings management. This happens because manager has had a larger share than that offered by the company with the implementation of the ESOP program, so that managers focus more responsible with the development of the company and not too take the initiative in following the ESOP program.

Based on the results of this study can be stated that the existence of ESOP program can increase the occurrence of earnings management. The management will try to increase the stock price at the end of the year to get a big profit without paying attention to the shareholders. However, with good oversight of the board of commissioners and the existence of management ownership may reduce the occurrence of earnings management.

\section{CONCLUSIONS AND SUGGESTIONS}

\section{Conclusions}

Researchers found that earnings management had a positive effect on increasing compensation earned through the ESOP program. Increased earnings management as management seeks to raised profits at the end of the year so that it can gain huge profits by increasing the share price at the end of the year so as to obtain huge profits by following the ESOP program. Increased earnings management due to the ESOP program can be reduced by the control of the board of commissioners and managerial ownership. The audit committee and institutional ownership has no influence over earnings management.

\section{Suggestions}

The researcher suggested that the companies implementing the ESOP program need to increase the tight supervision in the presence of board of commissioners, as well as their manage- 


\section{Jurnal Keuangan dan Perbankan | KEUANGAN}

Vol. 21, No. 3, Juli 2017: 425-435

rial ownership so that future actions can be reduced earnings management during the implementation of the ESOP program.

Subsequent research can use institutional ownership as a control variable, given that managerial ownership of firms in Indonesia is relatively small.

\section{REFERENCES}

Abbott, L.J., Parker, S., \& Peters, G.F. 2004. Audit Committee Characteristics and Restatements. Auditing: A Journal of Practice and Theory, 23(1): 69-87.

Astika, I.B.P. 2008. Pembentukan Return Saham Ekspektasi melalui Manajemen Laba di Sekitar Peristiwa Pengumuman Program Opsi Saham Karyawan. Jurnal Aplikasi Manajemen, 8(3): 826835.

Asyik, N.F. 2006. Dampak Penyaatan dan Nilai Wajar Opsi pada Pengaruh Magnituda Kompensasi Program Opsi Saham Karyawan terhadap Pengelolaan Laba. Simposium Nasional Akuntansi IX Padang.

Balsam, S., Chen, L.H., \& Sankaraguruswamy, S. 2003. Earnings Management Prior to Stock Option Grants. Working Paper. Temple University dan Georgetown University.

BAPEPAM. 2006. Pembentukkan dan Pedoman Pelaksanaan Kerja Komite Audit.

Bergstresser, D. \& Philippon, T. 2006. CEO Incentives and Earnings Management. Journal of Financial Economics, 80(3): 511-529.

Boediono, G.S.B. 2005. Kualitas Laba: Studi Pengaruh Mekanisme Corporate Governance dan Dampak Manajemen Laba dengan Menggunakan Analisis Jalur. Simposium Nasional Akuntansi VIII Solo.

Cadbury Committee Report. 1992. Report of the Cadbury Committee on the Financial Aspects of Corporate Governance. London: Gee.

Chen, C.R. \& Steiner, T.L. 2000. Tobin's Q, Managerial Ownership, and Analyst Coverage: A Nonlinier Simultaneous Equations Model. Journal of Economics and Business, 52(4): 365-382.
Cheng, Q. \& Warfield, T.D. 2005. Equity Incentives and Earnings Management. The Accounting Review, 80(2): 441-476.

Cheng, Q., Warfield, T., \& Ye, M. 2009. Equity Incentives and Earnings Management: Evidence from the Banking Industry. Journal of Accounting, Auditing and Finance, 26(2): 317-349.

Cornett, M.M., Marcus, A.J., Saunders, A., \& Tehranien, H. 2006. Earnings Management, Corporate Governance, and True Financial Performance. Working Papers, 1-28.

Herdinata, C. 2012. Reaksi Pasar terhadap Pengumuman Employee Stock Ownership Program. Jurnal Keuangan dan Perbankan, 16(1): 77-85.

Hermeindito. 2004. Asymmetry Information and Management Control: Sensitivity Analysis of Investment and Leverage on Selecting Source of Financing. Disertasi. Ilmu Ekonomi Manajemen Universitas Gajah Mada.

Ikatan Akuntan Indonesia. 2010. ED PSAK No. 35 (2010): Pembayaran Berbasis Saham.

Iqbal, S. \& Fachriyah, N. 2005. Corporate Governance Sebagai Alat Pereda Praktik Manajemen Laba (Earnings Management). Jurnal Akuntansi dan Keuangan, 6(4): 25-43.

Jensen, M.C. \& Meckling, W.H. 1976. Theory of The Firm: Managerial Behavior, Agency Costs, and Ownership Structure. Journal of Financial Economics, 3(4): 305-360.

Hartono, J. 2010. Teori Portofolio dan Analisis Investasi. Edisi Ketujuh. Yogyakarta: BPFE.

Kim, J. \& Graskamp, E. 2006. Why Stock Options Still Make Sense. Financial Executive, 22: 45-47.

Krishnan, G.V. 2003. Does Big-Six Auditor Industry Expertise Constrain Earnings Management? Accounting Horizon, 17: 1-16.

Kumaat, L.C. 2013. Corporate Governance dan Struktur Kepemilikan terhadap Manajemen Laba dan Kinerja Keuangan. Jurnal Keuangan dan Perbankan, 17(1): 11-20.

Kusuma, I.M.G.A. 2014. Pengaruh Konservatisme terhadap Hubungan Employee Stock Option Plan 


\section{The Role of Employee Stock Option Plan to Reduce in Earnings Management Actions}

Namla Elfa Syariati, Bambang Subroto, Wuryan Andayani

dengan Manajemen Laba. E-Jurnal Akuntansi Universitas Udayana, 7(2): 414-430.

Midiastuty, P.P. \& Machhfoedz, M. 2003. Analisis Hubungan Mekanisme Good Corporate Governance dan Indikasi Manajemen Laba. Simposium Nasional Akuntansi IX Padang.

Mitra, S. 2002. The Impact of Institutional Stock Ownership on A Firm's Earnings Management Practice: An Empirical Investigation. Dissertation. Louisiana State University.

Rahayu, R. \& Cahyati, A.D. 2015. Komparasi Asimetri Informasi Sebelum Dan Sesudah Konvergensi Ifrs (Studi Kasus pada Perusahaan Agriculture dan Mining yang Terdaftar di BEI). Jurnal Widya Warta, 1: 854-981.

Richardson, V.J. 1998. Information Asymmetry and Earnings Management: Some Evidence. Review of Quantitative Finance and Accounting, 15(4): 325-347.

Scott, W.R. 2012. Financial Accounting Theory. $6^{\text {th }}$ Edition. Toronto: Prentince Hall
Schabus, M. 2012. Equity Incentives and Opportunistic Real Earnings Management. Master Thesis.

Sulistyanto, S. 2008. Manajemen Laba: Teori dan Model Empiris. Jakarta: Grasindo.

Trebucq, S. 2004. The Effect of ESOPs on Performance and Risk: Evidence from France. Journal Corporate Ownership and Control, 1(4): 81-93.

Wedari, L.K. 2004. Analisis Pengaruh Proporsi Dewan Komisaris dan Keberadaan Komite Audit terhadap Aktivitas Manajemen Laba pada Perusahaan Publik di Indonesia. Tesis. Fakultas Ekonomi Universitas Gajah Mada.

Yermack, D. 1997. Good Timing: CEO Stock Option Awards and Company News Announcements. The Journal of Finance, 52(2): 449-476. 